\title{
ANTIMETABOLITES PRODUCED BY MICROORGANISMS. II ${ }^{1)}$
}

\section{L-2-AMINO-4-PENTYNOIC ACID}

\author{
James P. Scannell, David L. Pruess, Thomas C. Demny, \\ Florence Weiss, Thomas Williams and Arthur Stempel \\ Chemical Research Department, Hoffman-La Roche Inc., \\ Nutley, New Jersey 07110 , U. S. A.
}

(Received for publication January 21, 1971)

L-2-Amino-4-pentynoic acid was isolated from a streptomycete fermentation and shown to inhibit the growth of Bacillus subtilis in a chemically defined medium. This growth inbibition was reversed by L-methionine or L-leucine.

Recently several laboratories ${ }^{2 \sim 11}$ have been interested in the search for antimetabolites in fermentation broths. Such compouds are, ordinarily, not observed in conventional antibiotic screens due to the presence of reversing metabolites in the complex media commonly employed. However, by the use of chemically defined minimal media ${ }^{22}$ it is possible to detect antimetabolite activities and, by selectively supplementing the assay medium with known substances, to determine which compounds relieve the growth inhibition.

In this paper we report the isolation of an antimetabolite of $\mathrm{L}$-methionine and L-leucine from a fermentation broth produced by an unidentified streptomycete*. The substance which has not been reported in natural sources proved to be L-2amino-4-pentynoic acid identical with an authentic sample prepared from synthetic racemic material ${ }^{13)}$ by enzymatic resolution.

\section{Experimental}

\section{General Methods}

All melting points were taken with a Thomas Hoover capillary apparatus and are corrected. IR spectra were obtained in $\mathrm{KBr}$ discs with either the Beckman IR-9 or the Perkin-Elmer Model 621 spectrophotometer. NMR spectra were obtained in $\mathrm{D}_{2} \mathrm{O}$ using the Varian HA-100 instrument. Ultraviolet spectra were determined with a Beckman DB-G spectrophotometer, mass spectra with a GEC 21-110 mass spectrometer using a direct introduction probe, and optical rotations were taken with a Perkin-Elmer 141 polarimeter. The purity of preparations was checked using the Technicon amino acid analyzer and by means of thin-layer chromatography with Merck cellulose $F$ plates using as developing solvent, butanol - acetic acid - water $(12: 3: 5)$. Electrophoresis was carried out at $200 \mathrm{~V}$ using the Gelman apparatus. The F \& M Model 402 equipment was used for vapor phase chromatography.

* Streptomyces sp. \#8-4(HLR-599A), isolated 1966 from a garden soil of New Brunswick, N. J., kindly supplied by Prof. H. Lechevalier, Institute of Microbiology, Rutgers University, The State University of New Jersey. 
II. Microbiological Assay

A paper-disc agar-diffusion assay was used to detect the antimetabolite. The chemically-defined minimal-medium of Davis and MinGIoli ${ }^{14)}$ was used for the bioassay. Five $\mathrm{ml}$ portions of inoculated liquefied agar were pipetted into $100 \times 15 \mathrm{~mm}$ Petri dishes. After the agar solidified, the dishes were stored at $4^{\circ} \mathrm{C}$. For the bioassay of chromatograms, $35.6 \times 16.5 \mathrm{~cm}$ pans containing $150 \mathrm{ml}$ of agar were prepared. Dishes and pans were stored for no longer than one week in the cold. Inoculum was prepared with Bacillus subtilis NRLL-558 cells grown overnight at $35^{\circ} \mathrm{C}$ on a rotary shaker $(2-$ inch $(5-\mathrm{cm})$ stroke, 250 r.p.m.) in $500 \mathrm{ml}$ Erlenmeyer flasks containing $100 \mathrm{ml}$ of the inoculum medium described below. Cells were washed three times with water to remove excess nutrients and adjusted to an optical density of 1.2 (wave length, $500 \mathrm{~nm}$; path length, $15.5 \mathrm{~mm}$ ); $30 \mathrm{ml}$ of the washed cell suspension was added per liter of liquefied agar just prior to distribution.

A paper disc (Schleicher and Schuell, 12.7-mm diameter) was saturated with a solution of metabolite, either L-methionine or L-leucine at $0.1 \mathrm{~g} /$ liter, and placed on an assay plate. After thirty minutes, a second disc saturated with sample solution was placed near the first disc (one inch center to center). A third disc was then saturated with sample and placed alone on a separate assay plate. Both plates were incubated at $35^{\circ} \mathrm{C}$ overnight. A zone of inhibition was present around the disc on the plate without metabolite solution and a crescent-shaped zone was present on the plate with metabolite. Quantitative bioassays were also carried out since the diameter of the zone of inhibition was found to be proportional to the $\log$ of the antimetabolite concentration between 1 and $30 \mu \mathrm{g} / \mathrm{ml}$.

\section{Fermentation}

Spores of an unidentified streptomycete* were added to 6-liter Erlenmeyer flasks containing 2 liters of inoculum medium composed of (in $\mathrm{g} /$ liter): Bacto-peptone (Difco), 6 ; N-Z-Amine type A (Sheffield), 4; yeast autolyzate (National Yeast Products), 3; beef extract (Wilson), 1.5 ; and glucose, 1.0. The flasks were incubated at $28^{\circ} \mathrm{C}$ for 96 hours on a rotary shaker (220 r.p.m. with a 2 -inch $(5-\mathrm{cm})$ stroke). Four liters of inoculum were added to 300 liters of fermentation medium containing (in $\mathrm{g} /$ liter): $\mathrm{NaCl}, 13$; Cerelose (Corn Products) $11 ; \mathrm{MgSO}_{4} \cdot 7 \mathrm{H}_{2} \mathrm{O}$, 6.35 ; Bacto-peptone (Difco), 5.0 ; Bacto-yeast extract (Difco), $3.0 ; \mathrm{KCl}, 0.72 ; \mathrm{CaCl}_{2}, 0.50 ; \mathrm{FeSO}_{4} \cdot 6 \mathrm{H}_{2} \mathrm{O}, 0.25$. The culture was incubated at $28^{\circ} \mathrm{C}$ in a $300-$ liter fermentor, aerated at 170 liters $/ \mathrm{min}$. and agitated at 200 r.p.m. Silicone antifoam (Dow Corning AF) was added as needed to control frothing. After 68 hours of incubation the fermentation broth was filtered through infusorial earth by centrifugation.

\section{Preliminary Characterization}

The antimetabolite activity in the filtered broth was shown to be stable at $\mathrm{pH}$ values 2,7 and 10 for one hour at $50^{\circ} \mathrm{C}$. It was not adsorbed onto charcoal nor extracted into organic solvents. During electrophoresis at $\mathrm{pH} 3$ and 10 it moved as a cation and anion respectively. Thus the good $\mathrm{pH}$ stability and ionic nature of the compound permitted full use of ion-exchange resins.

\section{Isolation Procedure}

The filtered broth (180 liters) containing $25 \mathrm{~g} /$ liter solids and $9.7 \mathrm{mg} /$ liter antimetabolite was treated with $10 \mathrm{~g} /$ liter of Darco G-60. After filtration with Gelite, the filtrate and wash contained $100 \%$ of the activity.

The filtrate was passed through a 12 inch diameter column containing 50 liter Dowex $50 \mathrm{~W} \times 4$ resin $(50 \sim 100 \mathrm{mesh}$, in the hydrogen ion form). The activity was then eluted from the resin with $5 \%$ aqueous pyridine solution. From 75 liters of eluate, $197 \mathrm{~g}$ of solids were obtained after concentration and lyophilization. Recovery, $90 \%$; 
purification, 20 fold.

A column, $6 \mathrm{~cm}$ in diameter, filled to a height of $60 \mathrm{~cm}$ with 2 liters of AG $1 \times 8$ (200 400 mesh anion-exchange resin in the bicarbonate form), was charged with $60 \mathrm{~g}$ of solids obtained above, dissolved in 400 $\mathrm{ml}$ water and adjusted to $\mathrm{pH} 8.9$ with $25 \%$ trimethylamine solution. The resin was eluted with $0.2 \mathrm{M}$ trimethylammonium bicarbonate buffer ${ }^{15) *}$ adjusted to $\mathrm{pH} 9.3$ with $25 \%$ trimethylamine solution. The activity was present in 2 liters of eluate after 13 liters had passed through the column. After evaporation at reduced pressure, $2.6 \mathrm{~g}$ of solids were obtained. Recovery, $85 \%$; purification, 20 fold.

Cation-exchange chromatography was then carried out by dissolving $2.0 \mathrm{~g}$ of the solids in $15 \mathrm{ml}$ of distilled water and applying the solution onto $750 \mathrm{ml} \mathrm{AG} 50 \mathrm{~W} \times 4$, (50 100 mesh, hydrogen ion form ; colum dimensions, $42 \mathrm{~cm} \times 4.8 \mathrm{~cm}$ ). After washing the material onto the resin with $100 \mathrm{ml}$ distilled water the column was eluted with $1 \mathrm{~N}$ aqueous HCl. After 2.05 liters of eluate had been collected, the active material was eluted in $370 \mathrm{ml}$. This eluate was evaporated to dryness and the residue was

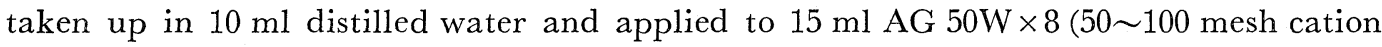
exchange resin in the hydrogen ion form). After washing with $50 \mathrm{ml}$ distilled water, the resin was eluted with $10 \%$ aqueous pyridine solution. The pyridine eluate was evaporated to dryness and the residue, $296 \mathrm{mg}$, (recovery $85 \%$, purification 5.8 fold) was crystallized from aqueous ethanol (yield, $159 \mathrm{mg}$; recovery, $70 \% ; 1.1$ fold). (Overall recovery $45 \%$, overall purification 3,000 fold). After recrystallization from aqueous ethanol, colorless needles of L-2-amino-4-pentynoic acid, III (Fig. 1) were obtained, m.p. $241 \sim 242^{\circ}$ (dec.). IR ( $\left.\mathrm{KBr}\right): 3300(\mathrm{H}-\mathrm{C} \equiv), 1600$ (carboxylate $\left.\mathrm{G}=\mathrm{O}\right) \mathrm{cm}^{-1} ; \mathrm{NMR}\left(\mathrm{D}_{2} \mathrm{O}\right.$, $8 \mathrm{mg}$ ext TMS) $\delta=4.34$ (t, $1, \mathrm{~J}=5.5 \mathrm{~Hz}, \mathrm{CH}_{2}-\mathrm{CH}-$ ), 3.28 (d of d, 2, J=5.5 and $2.5 \mathrm{~Hz}$, $\left.\equiv \mathrm{C}-\mathrm{CH}_{2}{ }^{-}\right), 2.97(\mathrm{t}, 1, \mathrm{~J}=2.5 \mathrm{~Hz}, \underline{\mathrm{H}}-\mathrm{C} \equiv)$; mass spectrum, $\mathrm{m} / \mathrm{e}$ at $74,68,41$ and 39 . $[\alpha]_{\mathrm{D}}^{25}-31.1^{\circ}\left(c 1, \mathrm{H}_{2} \mathrm{O}\right) ;-5.5^{\circ}(c 1,5 \mathrm{~N} \mathrm{HCl})$.

Anal. calcd for $\mathrm{C}_{5} \mathrm{H}_{7} \mathrm{NO}_{2}$ : C $53.09, \quad \mathrm{H} 6.24, \quad \mathrm{~N} 12.38$.

Found :

C $53.02, \quad$ H $6.46, \quad \mathrm{~N} 12.40$.

VI. Reduction of III to L-norvaline, IV

A solution of $2 \mathrm{mg}$ of III in $0.2 \mathrm{ml} \mathrm{H} \mathrm{H}_{2} \mathrm{O}$ and $1 \mathrm{ml}$ ethanol containing $2 \mathrm{mg} 5 \% \mathrm{Pd}$ on charcoal slurried in $10 \mathrm{ml}$ ethanol was reduced in the Brown ${ }^{2}$ hydrogenator. After 45 minutes of vigorous stirring in the hydrogen atmosphere, the reaction was terminated and the reduction product was separated from the catalyst by filtration. Thin layer chromatography on cellulose with ethanol-wather (4:1) developing solvent indicated that III had been converted entirely to a compound with the same $\mathrm{Rf}$ as

\footnotetext{
* This exceptionally volatile buffer is completely removed by a single evaporation at $40^{\circ} \mathrm{C}$ and $25 \mathrm{~mm}$.
} 
norvaline. Vapor phase chromatography of the $\mathrm{N}$-trifluoroacetylprolyl derivatives ${ }^{16)}$ of the methyl esters of both the reduction product and an authentic sample of Lnorvaline showed that both had the same retention times, thus indicating an $\mathrm{L}$-configuration.

VII. Resolution of D, L-2-Amino-4-Pentynoic Acid, I

A. Acetylation of I to II: To a suspension of 0.09 mole $(10.2 \mathrm{~g}) 1^{13)}$ in $620 \mathrm{ml}$ boiling acetic acid, $13.6 \mathrm{~g}$ acetic anhydride was added. After 10 minutes at reflux the solution was allowed to cool to $25^{\circ} \mathrm{C}$ and evaporated at reduced pressure to an oil. After addition and evaporation of $3 \times 10 \mathrm{ml}$ distilled water, the residue was crystallized from acetone to yield $10.9 \mathrm{~g}$ of $\mathrm{N}$-acetyl-D, L-2-amino-4-pentynoic acid (80\%, m.p. 137 $\sim 139^{\circ} \mathrm{C}$ ). IR $(\mathrm{KBr}): 3330$ (amide $\left.\mathrm{NH}\right) ; 3300(\mathrm{H}-\mathrm{C} \equiv \mathrm{H}): 1745$ (carboxylic $\left.\mathrm{C}=\mathrm{O}\right) ; 1620$ (amide $\mathrm{C}=\mathrm{O}$ ) $\mathrm{cm}^{-1}$.

Anal. calcd for $\mathrm{C}_{7} \mathrm{H}_{9} \mathrm{NO}_{3}$ : C 54.19, $\mathrm{H} 5.85, \quad \mathrm{~N} 9.03$.

Found: $\quad$ C 54.38, H 6.06, N 9.08.

B. Enzymatic resolution of II : The $\mathrm{pH}$ of a solution of $10 \mathrm{~g}$ of II in $550 \mathrm{ml}$ deionized water was adjusted to 7.7 with $2 \mathrm{~N}$ lithium hydroxide. Hog kidney acylase* $80 \mathrm{mg}, 4,400$ units, dissolved in $20 \mathrm{ml}$ deionized water was added to the substrate solution and the reaction was followed by quantitative ninhydrin assay. After 4 hours at $37^{\circ} \mathrm{C}$, the reaction was $94 \%$ complete and incubation was continued an additional 12 hours.

C. Isolation of $\mathrm{V}$ : The enzymatic digest solution was concentrated to $180 \mathrm{ml}$ and passed through $300 \mathrm{ml}$ of a cation-exchange resin, AG $50 \mathrm{~W} \times 8(50 \sim 100 \mathrm{mesh}$ in the hydrogen ion form) in a column, $6.0-\mathrm{cm}$ diameter, filled to a height of $10 \mathrm{~cm}$. The effluent and 2 liters of distilled water wash of the column were combined and concentrated to a thick syrup which was taken up in acetone. Upon cooling $2.45 \mathrm{~g}$ of $\mathrm{V}$ crystallized. An additional $0.7 \mathrm{~g}$ of material was obtained by concentrating the mother liquors (total yield, $62 \%$ ). Recrystallization from a mixture of acetone and petroleum ether (B.R. 30 60), gave pure N-acetyl-D-2-amino-4-pentynoic acid (m.p. 126 $127^{\circ} \mathrm{C}$ ). IR $(\mathrm{KBr})$ : essentially the same as that for II.

Anal. calcd for $\mathrm{C}_{7} \mathrm{H}_{9} \mathrm{NO}_{3}$ : C 54.19, $\mathrm{H} 5.85, \quad \mathrm{~N} 9.03$.

Found: $\quad$ C 54.38, H 5.82, N 9.00.

$[\alpha]_{\mathrm{D}}^{25}-26.1^{\circ}\left(c 1, \mathrm{H}_{2} \mathrm{O}\right) ;-37.8(c 1,5 \mathrm{~N} \mathrm{HCl})$.

D. Isolation of III : The column, after elution of V, was then eluted with $10 \%$ aqueous pyridine solution and fractions containing significant amounts of ninhydrin positive material were combined and concentrated. Crystalline III ( $2.72 \mathrm{~g}, 75 \%$ yield) was obtained from aqueous ethanol. Recrystallization gave pure L-2-amino-4-pentynoic acid, m.p. $248 \sim 249^{\circ} \mathrm{C}$ (dec.). IR $(\mathrm{KBr})$ : the same as the material isolated from the fermentation broth. $[\alpha]_{\mathrm{D}}^{25}-32.6^{\circ}\left(c 1, \mathrm{H}_{2} \mathrm{O}\right) ;-5.0^{\circ}(c 1,5 \mathrm{~N} \mathrm{HCl})$.

Anal. calcd for $\mathrm{C}_{5} \mathrm{H}_{7} \mathrm{NO}_{2}$ : C 53.09, H 6.24, N 12.38 .

Found: $\quad \mathrm{C} 53.17, \mathrm{H} 6.18, \mathrm{~N} 12.53$.

E. Hydrolysis of $\mathrm{V}$ to $\mathrm{VI}$ : A solution of $2.4 \mathrm{~g}$ of $\mathrm{V}$ in $30 \mathrm{ml} 2 \mathrm{~N} \mathrm{HCl}$ was refluxed for 2 hours. After evaporation at reduced pressure and addition and evapora-

* Hog kidney acylase. Purchased from Mann Research Laboratories, New York, N. Y. 
tion of $20 \mathrm{ml}$ distilled water 3 times, the residue was taken up in water and the $\mathrm{pH}$ adjusted to 6.0 with $\mathrm{NH}_{4} \mathrm{OH}$. Solvent was removed at reduced pressure and the residue crystallized from aqueous ethanol to give $\mathrm{D}-2$-amino-4-pentynoic acid $(0.91 \mathrm{~g}$, $52 \%)$. Additional crystalline material was obtained from mother liquors but extensive work up was required to remove the last traces of ammonium chloride from the product. Twice recrystallized material melted at $245 \sim 248^{\circ} \mathrm{C}$ (dec.). The IR was essentially the same as that for I. $[\alpha]_{\mathrm{D}}^{25}+32.9^{\circ}\left(c 1, \mathrm{H}_{2} \mathrm{O}\right) ;+6.0^{\circ}(c 1,5 \mathrm{~N} \mathrm{HCl})$.

Anal. calcd for $\mathrm{C}_{5} \mathrm{H}_{7} \mathrm{NO}_{2}$ : C 53.09, $\mathrm{H} 6.24, \quad \mathrm{~N} 12.38$.

Found :

C $52.81, \quad$ H $6.23, \quad \mathrm{~N} 12.26$.

\section{Discussion}

The physical chemical properties of III, in particular the nuclear magnetic resonance spectrum permitted the structural proposal, 2-amino-4-pentynoic acid. The infrared spectrum showed the compound to be an $\alpha$ amino acid and a sharp band at $3300 \mathrm{~cm}^{\sim 1}$ indicated the probable presence of a terminal acetylene group. The four non-exchangeable protons in the $\mathrm{nmr}$ spectrum could be assigned as follows: $\mathrm{HC} \equiv \mathrm{CCH}_{2} \mathrm{CH}$, with long distance coupling of the methylene protons to the acetylenic proton. The structure was strongly supported by the fragmentation pattern found in mass spectrometry which contained, in addition to the decarboxylation fragment, other fragments consistent with cleavage between the $\alpha$ and $\beta$ carbon atoms. Vapor phase chromatography analysis of the methyl ester of the trifluoroacetylprolyl derivative indicated an L-configuration. Further confirmation was obtained by reduction to L-norvaline.

Finally the synthetic racemic mixture ${ }^{13)}$, was resolved enzymatically after conversion to the $\mathrm{N}$-acetyl derivative and the $\mathrm{L}$-isomer was shown to be the compound obtained by reduction of the antimetabolite by comparison of the optical rotations.

\section{Acknowledgements}

We thank the physical chemistry department at Hoffman-La Roche Inc. under Dr. P. Bommer and the fermentation pilot plant under Mr. B. TABEnkin for their participation in the project.

\section{References}

1) Scannell, J. P.; D. L. Pruess, T. C. Demny, T. Williams \& A. Stempel : L-3(2,5-Dihydrophenyl) alanine, an antimetabolite of L-phenylalanine produced by a Streptomycete. J. Antibiotics 23 : 618 619, 1970

2) Stapley, E. O.; T. C. Demny, A. K. Miller \& H. B. Woodruff : Histidomycin. I. Production by Nocardia histidans and biological characterization. Antimicr. Agents \& Chemoth.- 1966 : 595 602, 1967

3) Hanka, L. J.; M. E. Bergy \& R. B. Kelly : Naturally occurring antimetabolite related to biotin. Science $154: 1667 \sim 1668,1966$

4) Argoudelis, A. D.; R. R. Herr, D. J. Mason, T. R. Pyke \& J. F. Zieserl : New amino acids from streptomyces. Biochemistry $6: 165 \sim 170,1967$

5) Stapley, E. O.; T. W. Miller, J. M. Mata \& D. Hendlin : L-4-Oxalysine, an antimetabolic antibiotic of microbial origin. Antimicr. Agents \& Chemoth.-1967: 401 406, 1968

6) Kelly, R. B.; D. G. Martin \& L. J. Hanka : 2-Amino-4-methy1-5-hexenoic acid, a naturally occurring antimetabolic antibiotic. Canad. J. Chem. $47: 2504 \sim 2506,1969$

7) Baggaley, K. H.; B. Blessington, C. P. Falshaw, W. D. Ollis, L. Chaiet \& F. J. Wolf: The constitution of stravidin, a novel microbiological product. Chem. Commun. : 101 102, 1969

8) Keller-Schierlein, W.; K. Poralla \& H. Z̈̈hner : Stoffwechselprodukte von Mikroorganismen Isolierung, Identifizierung und Wirkungweise von Ketomycin [(R)-3-Cyclohexenylglyoxysäure] und dessen Umwandlungsprodukt 3-Cyclohexenylglycin. Arch. Mikrobiol. 67 : 339 356, 1969

9) Keller-Schierlein, W.; J. Sauerbier, U. Vogler \& H. Z̈̈hner : Stoffwechselprodukte von Mikroorganismen-Aranciamycin. Helv. Chim. Acta 53:779 789, 1970 
10) Balerna, M.; W. Keller-Schierlein, C. Martius \& H. Zähner : Stoffwechselprodukte von Mikroorganismen-Naphthomycin, ein Antimetabolit von Vitamin K. Arch. Mikrobiol. 65 : 303 317, 1969

11) Korobkuva, T. P.; L. P. Terekhova \& T. S. Maksimova: Occurrence of antibiotics possessing properties of leucine antimetabolites. Antibiotiki $15: 936 \sim 940,1970$

12) Hanka, L. J. : In vitro screen for antimetabolites. Proc. 5th Int. Congr. Chemother. B 9/2 : 351 357, 1967

13) Gershon, H.; J. S. Meek \& K. Dittmer : Propargylglycine : an acetylenic amino acid antagonist. J. Am. Chem. Soc. $71: 3573 \sim 3574,1949$

14) Davis, B. D. \& E. S. Mingrolr : Mutants of Escherichia coli requiring methionine or vitamin $\mathrm{B}_{12}$. J. Bact. $60: 17 \sim 28,1950$

15) Porath, J. : Methodological studies on zone-electrophoresis in vertical columns. Biochim. Biophys. Acta $22: 151 \sim 175,1956$

16) Westley, J. W. : Peptides : Chemistry and biochemistry. Eds : S. Lande \& B. Weinstein. p. 359, Marcel Dekker, New York, 1970 